\title{
Feminist approaches in the geographies of religion: experience, emotions, everydayness and embodiment in postsecular society and space
}

\author{
Kamila Klingorová*
}

Charles University, Faculty of Science, Department of Social Geography and Regional Development, Czechia

* Corresponding author: kamila.klingorova@natur.cuni.cz

\begin{abstract}
Recently, geography has included in research the increasing role of religion in postmodern Western society and space. Religion is no more being understood as an objective truth, but as an individual experience of a person with a significant impact on the perception of space and place-making. This problematic undoubtedly requires a new theoretical and empirical perception in the new geographies of religion. This paper appeals for the geographical study of the relation between religion and (postsecular) space could be significantly enhanced using feminist approaches, which enable the inclusion of personal experiences and individuality in the geographies of religion. Using the feminist approaches, the changes in religious climate, ongoing currently in the West, including Czechia, could be better addressed in geography. Thus, the paper theoretically discusses the potential of feminist approaches and argues especially for the relevancy of four topics, personal experience of people, emotions, embodiment, and the everydayness, which can offer new insights into understandings of the relation between religion and space. Similarly, methodologies used by feminist scholars provide unique option for getting to know how religious people interact with sacred as well as secular space. Therefore, the paper aims to justify the contribution of feminist approaches and the empirical research considering the creation of sacred space and framing the everyday religious experience of people.
\end{abstract}

\section{KEYWORDS}

feminist approach; sacred space; religious identity; place-making; everyday experience

Received: 6 March 2019

Accepted: 15 April 2020

Published online: 7 May 2020

Klingorová, K. (2020): Feminist approaches in the geographies of religion: experience, emotions, everydayness and embodiment in postsecular society and space. AUC Geographica 55(1), 123-133

https://doi.org/10.14712/23361980.2020.9

(C) 2020 The Author. This is an open-access article distributed under the terms of the Creative Commons Attribution License (http://creativecommons.org/licenses/by/4.0). 


\section{Introduction}

Religion is a diverse phenomenon which could be understood in many ways: as a cultural system, an institution, a specific belief in transcendence, or an individual emotional experience. All these forms address complex experiences of person and form her/ his relationship with the world itself. The cultural and institutional form of religion (e.g. churches, religious institutions or civilizations) has been the subject of social geography research for decades. However, the individual religious experience, its role in people's life, understanding and spatial patterns, started to be acknowledged in geography in the last two decades, approximately, particularly because this form of belief has been started to dominate in the current Western society, which is also the case of Czechia (Havlíček and Klingorová 2018; Nešpor 2018).

The individual religious experience is especially valuable in relation with postmodern values in society where individuality is an important variable. With the raise of postmodernity (Beckford 1992), the importance of religion and spirituality deepens, especially in relation to the social and cultural identity of people and in relation to public space (Cloke and Beaumont 2013; Beaumont and Baker 2011; Kong 2010). The reasons for the increase in the role of religion are to be found in the processes of globalization and migration, among others (Dwyer 2016; Henkel 2011; Kong 2010).

Furthermore, the form and function of religion is changing in postmodern space. These changes are described in the concept of postsecularisation (e.g. Williams 2015; Sturm 2013; Habermas 2008; Berger 1999). Religion is becoming more heterogeneous and is more often understood and lived as the individual experience of a person than as an objective truth formed by religious texts and institutions (Heelas and Woodhead 2005). Together with deinstitutionalization of religiosity, religion and spirituality moved from the 'officially sacred' space of churches and temples to the space of the ordinary everyday life of people (Klingorová and Gökarıksel 2018; Kong 2010; Gökarıksel 2009; Brace, Bailey, and Harvey 2006; Holloway 2003), which is also the case of Czechia (Havlíček and Klingorová 2018; Nešpor 2018). Generally speaking, religion and spirituality became dynamic variables which have a power to create and transform every space and cross-over every border in postsecular society (Gökariksel 2009).

Therefore, alongside with these societal changes, religion and spirituality are increasingly discussed in social geography (Dwyer 2016; Kong 2010; Dewsbury and Cloke 2009; Holloway 2006) as one category of people's identity as well as a determinant of space. In critical and new cultural geography, religion is an important variable as well because it enriches the discussion about the formation of social identities, inequalities and values on one hand, and the formation of space and place on the other (Dwyer 2016). The new geographies of religion (Kong 2010) are bounded with the new cultural geography in a way in which they study religion in the everyday life of ordinary people, focus on the dynamic relationships (between secularity and sacrality) in space, and use individual and qualitative approaches. Overall, the thinking of the new geographies of religion should move thematically from the 'big', traditional religions to spirituality and individual religiosity, empirically from religious authorities to women, young people and other minor groups, and from general patterns to experiences, spatially from temples and mosques to living rooms, and in scale from global differentiation of religion to human body.

Concerning the individual and emotional experience of a person with religion and/or transcendence, it is important to focus on 'how (do) different groups of men and women with different markers of social difference - race, class, age, disability, sexuality, locality - experience their religion and their use of religious space, and how do these people respond to other groups of men and women' (Hopkins 2009: 12). For such study, Hopkins (2009) pointed to the possibility of using feminist approaches in the geographies of religion.

In this paper, I would like to support this statement and argue that the studies of the relationship between person, religion and (postsecular) space could be well enhanced using feminist geographies. Even though the geographies of religion are not an increasingly developed subfield in Czechia, I believe that the feminist approaches in the studies of religion and space could significantly enrich discussion and, more importantly, empirical studies of religion and space in Czechia. I build on Kong's (2001, 2010) appeal for studying the 'poetics' of religious experience which needs to be understood at the scale of the human body. Even though in most of the geographies of religion literature, and in social science as a whole, feminist approaches have been considered mostly in relation with patriarchy and hierarchical relations, I argue that feminist approaches could be applied in a context of ordinary person, her/his emotions and body because they enable us not only to study gender and patriarchy, but also to emphasize the everyday level of experiencing religion and individual emotions relating to religion and spirituality of a person in space which is important in postmodern society. Thus, feminist approaches enable to address religious changes at the theoretical, conceptual and methodological level, change emotions and everydayness into analytical problems and, thus, include religion and spirituality as emotional and personal subjects into (empirical) spatial research. All these problems are very relevant in the context of Czech postsecular space and society.

Therefore, the main aim of this paper is to contribute to the interpretation of the relationship between 
religion and space from the feminist perspective and theoretically as well as methodologically develop the argument that religion and spirituality are present in the space of ordinary, everyday life of people, public and private. Apart from the obvious theme of patriarchy and gender hierarchy, I discuss and further expand four topics of the geographies of religion for which the feminist approach is relevant: emotions, lived experiences, everydayness and embodiment, arguing that these are the problems of the interaction of religion and space in the period of postsecular society which need to be further developed. Moreover, I argue that the methodological approach used in feminist geographies provides unique option for getting to know how religious people interact with postsecular private and public space in their everyday life.

\section{Postsecularism in geographical research}

Changes in the opinion of people on religion and churches relate to increasing social emphasis on postmaterial values in the Western world (cities mostly, Inglehart and Appel 1989). People who emphasize self-expression, self-development and quality of life over material goods put more stress on the way religion can help them with their personal development instead of security and safety under the roof of a church. Therefore, the institutionalized form of practicing religion and the religion of objective truth is decreasing while, at the same time, people increasingly prioritize subjective and privatized ideas about transcendence (Heelas and Woodhead 2005; Heelas 1996). They choose those ideas which help them in their personal self-development. Individual religion is often connected with Protestant Christianity and, usually, energies, esoterism, Eastern and pre-Christian traditions, however, every person can have different and very diverse ideas about transcendence. Some of the spiritual ideas became the basis of the so called new religious movements (Vojtíšek 2007; Heelas 1996) which concentrate on personal development, quality of life and controlling negative emotions. Therefore, the religion of subjective experience and individual spirituality plays an increasing role in public space of the 'West' nowadays (Heelas and Woodhead 2005), while traditional (church) religiosity is decreasing.

The processes outlined above have been described, analyzed and theorized in social sciences for many decades (started by Luckman 1967; Berger 1999; among others). Habermas (2008) described such processes as postsecularisation. He emphasizes intermingling of diverse forms of religion and spirituality in public space together with secularity, which altogether form the postsecular society and space (see more Havlíček and Klingorová 2018). 'Key to Habermas' idea of post-secularism is the integration of religious ways of being within a public arena shared by others who may practice different faiths, practice the same faith differently, or be non-religious in outlook' (Gökarıksel and Secor 2015: 21). Postsecularisation mostly designates the growing presence of religion in the public sphere and the growing plurality of religious communities (Williams 2015; Cloke and Beaumont 2013; Beaumont and Baker eds. 2011). Also, geographers of religion (e.g. Gökariksel and Secor 2015; Williams 2015) speak about greater respect for the diverse religious cultures of postsecular spaces. Since the society is more willing to live with religion (Cloke and Beaumont 2013) and especially with new religious movements, postsecularisation also brings about a shift in the public perception of the role and potential usefulness of religion in society. Postsecularisation is especially apparent in society in the West in about last 20-30 years (Henkel 2014; Cloke and Beaumont 2013; Beaumont and Baker 2011).

In geography, the discussion about postsecularisation was raised at the turn of the millennium (Kong 2010). In general, geography enriches postsecular theory questioning continuous secularization and analyzing the interaction of secularity and sacrality in space (see Havlíček and Klingorová 2018; della Dora 2018; Gökarıksel and Secor 2015; Williams 2015; Henkel 2014; Tse 2014; Cloke and Beaumont 2013; Olson et al. 2013; Beaumont and Baker 2011; Kong 2010). The thesis of this discussion reflects the theories described above and enriches it with spatial dimension. The main idea is that "crossing-over" in the public arena between the religious and the secular' occurs (Cloke and Beaumont 2013: 2). Thus, even though religion is (re)appearing in public space (Kong 2010), secularisation continues (Sturm 2013). The processes of secularisation and desecularisation of space therefore act simultaneously (see for example Havlíček and Klingorová 2018).

The 'postsecular turn' in geography comes hand in hand with the 'new' geographies of religion (Kong 2001) which separate the 'politics' of religious space from the 'poetics', first emphasizing power relation in the process of making sacred space, second highlighting sacred place-making as 'a part of people's experience of the religious' (Kong 2001: 218). This difference illustrates the same change as from the religion of objective truth to the religion of subjective experience. The 'politics' of religion is closely tied with problems such as differences in religious adherence, diffusion of religions, differences in traditions and religious conflicts. In geographies of religion studies concerning these problems, quantitative data are used the most.

The 'poetics' of religious experience is more connected with personal identity of a person, her/his perception of sacredness (in space) and with creating religious community (Kong 2001). Apart from the 'poetics' of sacred, terms such as everydayness, perception, experience, identity, community, body, and diversity occur when going further beyond Kong's 
(2001, 2010) ideas. Among others, Kong (2010) asks to study the places beyond 'officially sacred' such as pilgrimage sites, religious schools or roadside memorials. However, one can argue that the places beyond 'officially sacred' should not be limited to places which hold religious symbols as Kong describes them and, thus, include places of the ordinary everyday life of people. The transcendence is more often present in spaces of everyday life of a person than in 'officially sacred' spaces (Klingorová and Gökarıksel 2018; Klingorová and Vojtíšek 2018; Finlayson 2012, 2017; Kong 2011; Holloway 2003, etc.), especially at the level of personal perception and experiences. People create sacred spaces for example through 'informal' religious practice (Klingorová and Vojtíšek 2018) or by experiencing their everyday activities 'through God' (Klingorová 2016). Thus, every space, even seemingly secular, could be perceived as sacred. Furthermore, the 'politics' of religion are being developed more at the global and national scale, while the 'poetics' of religious experience needs to be understood at the scale of the human body. Lastly, Kong argues that different geographies of religion of different groups of people, for example men, women, children, adults, elderly, should be theorized and their different experiences of sacred in public and private space should be studied.

Geographers of religion have already started to focus on religious experience in space and did a great job, however, there are still several topics, contexts, problems and examples which need to be taken into consideration and further developed. Development of these themes in the new geographies of religion requires theoretical and empirical approach which would allow to deal with its abstractness and focus on individual matters of life in private space. The question I ask is, therefore, how could feminist approach enhance Kong and others' calls for increased attention to religious experience of ordinary people?

\section{Agendas for feminist approaches}

In geography (and other disciplines as well), feminism had long time been understood as a concept seeking inclusion of gender hierarchy, patriarchy and women's experience into research. This agenda could be associated with the 'politics' where patriarchy relates to oppression and inequalities within religion. The relation between religion and the role of women and gender inequalities in society is still worldwide discussed subject (e.g. Tomalin 2013; Woodhead 2013; Seguino 2011; McGuire 2008; Inglehart and Norris 2003; Ingersoll 2003). It is very sensitive subject because gender discrimination is not only contained in the substance of religion, but is a result of its politicization and use in power relations as well. The specific relationship between religion and gender hierarchy is determined by the concrete social and cultural context (Klingorová and Havlíček 2015) which could, but does not have to, dominate in the given place, region, state, civilization, or cultural sphere.

Even though the problematics of patriarchy is undoubtedly important, feminist approaches should not be limited only to the study of gender and patriarchy. It might bring a broader perspective into the research on the relationship between religion and space. As defined within feminist geographies (e.g. Sharp 2009; Pratt 2009; McDowell and Sharp 1999; Nast 1994), feminist approaches take heterogeneity into account, focus on the (cultural) construction of identity of a person, and consider human body and emotions as research subjects. Here I find relation with the new geographies of religion which intend to focus on the 'poetics' of sacred and everyday experience of religion in postsecular space.

\subsection{Religious experience of women}

One exciting area to explore is the everyday experience of different people who belong to a particular religion, but also of people who interact with a space where such religion dominates. The focus on women experiencing religion in space has been well developing over last decade or so (e.g. Klingorová and Gökarıksel 2018; Olson et al. 2013; Gökarıksel 2007, 2009, 2012; Morin and Guelke 2007; Falah and Nagel 2005; Secor 2002, 2003; Dwyer 1999a,b). This body of scholarship takes without any doubt the biggest part of 'feminist' geographies of religion. It attempts to distance from the 'old' geography of religion where research focused on ordinary women's experience was underrepresented.

The initial assumption of such studies is the specific role of women adhering to a minor religion in a sacred space where a different major religion prevails, or in a secular space. Most typically, it is Muslim women in a secular or dominantly Christian space, e.g. Western and Central Europe. The problematic of the role of religious women within dissimilar religious space is strongly tied with politicization of secular or religious norms and values, and with feminist geopolitics (e.g. Gökarıksel and Secor 2015; Berghammer and Fliegenschnee 2011; Dowler and Sharp 2001). Very lively discussion is about different headscarf policies in Western Europe where the headscarf policies at the state level differ in relation to differences in gender equality, culture and religious dominance, from regulation to accommodation (Sauer 2009). The way headscarf policies and religious power relations in general are formed and experienced 'from below', meaning by ordinary people (women in this case), could be understood through the analysis of everyday spaces (Gökarıksel 2012). A closer look at the spaces of the everyday, ordinary life of people enables us to 'keep women visible in rapidly changing world conditions, where their activities tend to slip into the shadows of dominant models in the literature' (Dyck 2005: 234). 
Despite criticism of Kong (2010) who says that religions other than Islam are overlooked in geographies of religion, the problematics of Muslim women still dominates the debate. Most often, Islam is studied as a minor religion in the context of the dominantly secularized Western Europe (Berghammer and Fliegenschnee 2011; Dwyer 1999a,b), in Turkey (Gökarıksel 2009, 2012; Secor 2002, 2007) or in the Middle East (Fenster 2007). Problems raised in these geographic, social and cultural contexts justify such research themselves. Further, religious experience of Muslim women is strongly tied with veiling as a spatial practice expressing their religious identity (e.g. Gökarıksel 2009, 2012; Sauer 2009; Secor 2007; Dwyer 1999b). Through the practice of veiling, a women's embodied experience with religion could be studied at different levels, as well as Muslim women's contact with public space. 'Dress is important for understanding gender, religion, and space because it is an embodied practice through which religious ways of being are represented and enacted' (Secor 2007: 153). Veiling clearly expresses Muslim women's identity on the outside. A veiled women's interaction with space is, thus, a phenomenon whose analysis can enrich research on religion and space, especially in the case of secular and dissimilarly religious public space.

On the contrary, one may argue that studying ideologically non-conflicting relations between religion, women and space is important for identification of possible problems of such an interaction. However, for example, Christianity in secular or culturally Christian space (such as for example in the West) is not an experience significantly appearing on the outflow of human body. Laic Christianity does not show up in appearance or clothing of a woman, which enables her to better blend with the majority in a public space. The most common symbol of Christianity on woman's body, a cross necklace, is not very noticeable and often even doesn't express religiosity of its holder. A veil is also a symbol of Christianity but is nowadays used almost exclusively by Nuns. As unusual clothing of Christian women could be considered formal clothing worn by women on Sunday. Because Sunday is a day of a worship in many Christian churches, women consider Sunday as a 'day spent with God' (Klingorová 2016) and, therefore, wear more formal dress than weekdays.

However, formally dressed Christian women on their way to church or Nuns are not considered as members of a different culture in (for example) the West, which is not the case for veiled Muslim women. It makes the subject of Christian women experience less problem-related than Muslim women experience. But, in my point of view, there are other themes which desire to be developed such as the difference between Catholic and Protestant women experience in relation to confession or celibacy, the experience of women priests, women's role in the openness of Christian churches to broader society (the case of maternity or parental centers) and many more.

\subsection{Everyday life and space of religion}

As I mentioned above, the most resonating theme concerning women's experience with religion is veiling. But women's experience of religion doesn't belong only to public, but also to a private space. The contextual shift from the public to the private space in the geographies of religion could be considered as one of the most important contributions of feminist approaches. However, these two spaces - public and private - should not be separated because religion is crossing-over the borders of both spaces. Even though the everyday life of a person is more connected with the private space (but should not be interchanged) through activities such as housework, leisure time or commuting, everydayness is not limited only to private or public space, nor the everyday religious experience. In this part of the paper, I focus on everydayness as a concept crossing-over public and private space and described as the quotidian, ordinary, routine or everyday (contrasting to special, exceptional) activities of people and spaces where these activities are located (Pinder 2009). I understand everyday life as activities through which people experience space around them. Thus, everydayness can involve every activity of a person through which they live her/his life. The cultural turn switched the attention of geography to such places and activities and how these are experienced, shaped and transformed by people.

For geographies of religion, 'the everyday is critical because the boundaries between the secular and the religious are constituted and maintained, as well as destabilized, transgressed and reformed, on a daily basis through seemingly mundane practices' (Gökarıksel 2012: 6). The geographies of religion have already started turning their interest from 'special' places such as church or temple to lived religion (MacKian 2012; McGuire 2008; Hunt 2005; Kong 2001 etc.) and to everyday practice and manifestations of faith (or secularity) in everyday spaces (Klingorová and Gökarıksel 2018; Dwyer 2015; Olson et al. 2013; Vincett et al. 2012; Gökarıksel 2009 etc.).

The routine everyday religious practices of individuals are complex, dynamic and lived and, thus, can be very different from practices of religious institutions and organizations (McGuire 2008). One of the possible strategies for dealing with everydayness in the geographies of religion is to let the definition of everydayness be a subjective understanding of an examined group and, therefore, to work with everydayness in a way which the actors subjectively describe it (Klingorová and Gökarıksel 2018). Another problem which the researcher should deal with is that research on experiencing religion in everyday life and space could avoid places which are 'special' or extraordinary, both in the context of the everyday life of a person and in a religious context, places such as pilgrimage sites, sacred mountains and other places which are not visited on regular basis, but on special 
occasions and only once. However, visiting such places can have an important influence on an individual's experience of faith. The impression can even be projected into everyday experience and formation of everyday places of religion.

\subsection{Emotions and lived religion}

Everyday spatial experience with religion is strongly tied with the emotional and subjective experience of individuals (Bartolini et al. 2017; Finlayson 2012; Nast and Pile 1998 etc.). Religion is an emotional experience and emotions play a key role in the formation of sacred place (Klingorová and Gökarıksel 2018). Thus, individual and collective emotions should be considered in religion-geographic research. It was the feminist approaches which started the emotional turn in social geography (Davidson, Bondi, and Smith 2005; Pringle 1999) highlighting that feelings and emotions are important for geographic research because they form a way in which people perceive space and place (Davidson, Bondi, and Smith 2005). 'Emotional geographies emphasize how embodied emotions are connected to specific places and contexts because questions about how emotions are embodied and located merit further elaboration in the context of typical and less typical everyday lives' (Davidson, Bondi, and Smith 2005: 5). People assign meanings to places through emotions which reflect their subjective interpretation and perception (Sharp 2009). Thus, emotional geographies enrich research on perception of place and cultural geography in particular because emotions are gained with cultural values and determined by the circumstances and concepts of a particular culture (Pringle 1999).

Like other cultural patterns, religion forms the emotions and perception of religious, but also non-religious people. Even people who do not believe in God or other concrete transcendental power consider transcendence and energy in places of nature and a calm, pleasant environment where they can deeply think about life questions (Klingorová and Gökarıksel 2018). Thus, religion contributes to the meaning of sacred and secular places as well. Emotions related to religion can be positive, but also negative. Positive emotions prevail because religion usually brings peace, calmness, happiness, usefulness, satisfaction, and answers to important questions into an individual's life (Klingorová and Gökarıksel 2018). Negative emotions related to religion could be feelings of discomfort, shame, vulnerability and fear connected with everyday experience of exclusion, religious intolerance, or even racism (Hopkins 2006, 2007). Such negative emotions often importantly influence an individual's everyday time-space behavior when the person tries to avoid places where her/his religious identity is in the minority.

As discussed above, people have the most striking religious experiences in places beyond 'officially sacred' space (Dwyer 2016; Gökarıksel 2009) because such places are more 'lived'. For example, a library with exposed religious symbols, a tree on the edge of a meadow (Klingorová and Vojtíšek 2018), a kitchen unit or even a bus stop (Klingorová and Gökarıksel 2018) could become a sacred place for an individual through her/his emotional religious experience. Emotional geographies thus allow us to develop research on religious space and place, it's formation and transformation, considering everydayness and lived religion (MacKian 2012; McGuire 2008; Hunt 2005). The interest in religious emotions reflects the argument of McGuire (2008) who says that it is important to study religion not in a way which is defined by institutions, but in a way in which religion is lived in the everyday life of people. Of course, one cannot say that religious experience is weaker in a church or a temple, but religious experience in such 'officially sacred' places is more formed by religious symbolic, ritual and collective experience (Finlayson 2017) and less personal.

\subsection{Embodied experiences with religion}

Finally, feminist approaches might contribute to the research on religion and place by bringing the focus onto embodied experiences. Embodiment has a broad overlap with research on everydayness, emotions and women's experiences. Every research on religion works, necessarily, with embodied experiences such as baptism, marriage, confession, confirmation, or funeral (Dewsbury and Cloke 2009). Regular church visit is an (everyday) embodied experience as well (Wigley 2016). Furthermore, a human's body is an element in space on which religion can be visibly manifested. Religious people use their bodies to express their identity (Kong 2010) in, for example, wearing veils, skullcaps, cross necklaces, or vestment. A human's body outwardly reflects the individual's identity, values, and morality and, thus, becomes an indicator of religiosity. Simultaneously, a human's body is an instrument through which people religiously experience space (Kong 2010; Gökarıksel 2009; Holloway 2006; Bailey, Harvey, and Brace 2007 etc.).

Recently, the human body has gained more and more attention in social geography (Bailey, Harvey, and Brace 2007; Rodaway 1994). Research on embodiment could be enriching for studying religion and space, especially when we consider the body as an active subject. The body plays an important role in the production of a sacred (and secular) place (Holloway 2003) and, simultaneously, is the most 'private' and the most intensively experienced place in which religion manifests (or does not manifest).

Furthermore, a human body as a transcendence holder has the ability to bring sacrality into place and to make sense of sacred space (Holloway 2003, 2006; Sheldrake 2001), which reflects the ideas of the humanists Tuan or Buttimer (Kong 2001). According to Eliade (1959), sacred place is created in secular 
(profane in Eliade's words) space through sacred experience.

Thus, sacred place is part of space which gains special (transcendental, sacred, religious) meaning through ritual or religious experience of a person or group of people (Sheldrake 2001) who have (and share) interest in such a place. Sacred place therefore does not have to involve any religious symbols, it only can be created, transformed, perceived, or experienced with a presence of a body. Such places do not have to be identifiable at first sight. Thus, sacred place could be identified by an individual in any, seemingly secular space and 'the sacred is made and remade in everyday spaces through the embodied and emotional practices of religiously affiliated and non-affiliated' people (women in this case, Klingorová and Gökarlksel 2018: 56).

The current development in geographies of religion (e.g. Olson et al. 2013; Gökarıksel 2009; Holloway 2003,2006 ) includes the role of embodiment and emotions in production of sacred places (Finlayson 2012). It perceives the human body as 'the primary site through which transcendence and its associated religious authenticity can be achieved by bringing faith simultaneously outward and inward' (Olson et al. 2013: 1432). Further, research on embodied experiencing religion supports the thesis that sacred and secular space are inseparable because religion, through embodied experiencing, has the ability to get into every space of everyday life. Usually, the human body is not limited to 'officially sacred' or other spaces. The research on embodied experiences is, thus, 'a good starting point for challenging any site as being wholly sacred or wholly profane, emphasizing instead a relationship of spatial construction' (Olson et al. 2013: 1424) and transformation of space. Every sacred space should be understood in accordance with the person or people who created such place. The tension between the sacred and secular meaning of places exists at the material, symbolic, and ideological level (Gökarıksel 2009; Howe 2009; Kong 2001) and 'the duality of the sacred and secular breaks down and their geographies appear more fluid and transformative' (Klingorová and Gökarıksel 2018: 56). Thus, from the feminist perspective highlighting the role of human body, Eliade's understanding of sacred and secular spaces as two different, separated and incompatible spheres could be considered as overcome because each person can perceive and experience the same place differently.

\subsection{Methodological approach}

The themes defined and discussed above have common focus on problems of individual experience, everydayness, emotions and body from the empirical point of view. More attention is put on formation of personal identity of religious minority (Aitchison,
Hopkins, and Kwan 2007; Hopkins 2007) or majority (Gökarıksel and Secor 2017a; Olson et al. 2013; Hopkins et al. 2011; Gökarıksel and McLarney 2010) or formation of behavior and everyday practices (e.g. Gökarıksel and Secor 2015, 2017a,b; Wigley 2016; Holloway 2003). The empirical analysis should therefore acknowledge what is unique, specific and individual, such as the place, body or identity. Methods so far predominantly used in the geographies religion are not able to achieve these goals, especially those which have quantitative character. Methodological approach which consider all the personal nuances of religion is needed, for which we can look for inspiration in the feminist geographical research.

Even though the methods which are typical for feminist geographies are hard to generalize, two common characteristics are to be find: the feminist research primarily works with qualitative participative methods and analyze the problem in ordinary, everyday spaces from a specific point of view of a concrete group of people. These strategies were partly adopted by the already existing scholarship of 'feminist' geographies of religion. Also, the influence is obvious in comparison of preferred methods of the 'old' and the new geographies of religion. The 'old' geography of religion worked prevailingly with descriptive quantitative methods (Rinschede 1999), the research focused on macroregional, sociological and religionist analysis and methods were selected to describe the diffusion of religion and its influence on landscape. The new geographies of religion instead deal with local and personal specifics of the relationship between religion and space using behavioral approaches. The most commonly, combined methods inspired in ethnography, anthropology and sociology are used, for example combination of semistructured interviews with participant observation (Gökarıksel 2009), discourse analysis (Gökarıksel 2007) or statistical analysis (Besio 2007; more see at Gökarıksel 2012; Fenster 2007), or participative photography (Klingorová and Gökarıksel 2018; Klingorová and Vojtíšek 2018).

Generally, the most of researches which could be included in 'feminist' geographies of religion apply participative approaches engaging with (mostly) women (Klingorová and Gökarıksel 2018; Klingorová and Vojtíšek 2018; Gökarlksel and Secor 2015; Olson et al. 2013; Dwyer 1999a,b; 2015, Hopkins 2006; Secor 2002). Participative research enables to enter private space of involved person, analyze her/his emotional experience in detail (Pain 2004; Breitbart 2003), reflect specific conditions and knowledge of people, bring more authentic look (Noland 2006) and be more sensitive to minorities (Pain 2004). Further, participative methods allow research participant to decide alone which part (if ever) of private space is he/she willing to open for research. Also, participative research minimalizes the hierarchical relations between researcher and studied group and, thus, 
makes the discussion about sensitive themes such as inequality, abuse or minority religion easier. Participants are allowed to define themselves how they understand research themes such as religion, spirituality, everydayness, inequality, hierarchy etc. The research thus better reflects the real perception of a studied group.

Furthermore, methods in the new geographies of religions need to acknowledge secularity and secular space as well. Undoubtedly, lived religion and religious experience of people should not be limited only into sacred space. Also, people who do not adhere any institutionalized religion often deal with personal spirituality or individual religious experience which is hard to categorize or even describe by the participant itself. Thus, the perspective which reflects the individual though of a person and the local socio-cultural characteristics of a concrete space and place must be applied. These reasons lead again to the use of combined and participative methods, acknowledging the spatial aspect.

However, other methodological approaches such as descriptive or quantitative methods are to be considered as complementary or even the only suitable methods in many cases. Quantitative methods allow to acknowledge the general context and gain comparative view. Thus, the extensive research should be enriched with intensive research (and vice versa) which allows to move the research from general to personal context and from public to private space where the religion of subjective experience, prevailing in the postsecular society, acts the most.

\section{Conclusion}

The longstanding development which feminist geographies have undergone from the Geography of women through the Geography of gender relations to the Feminist geographies of difference (Pratt 2009) ended up with the main focus on the construction of identities of different people and emphasizing the plurality of experiences of people. In geographies of religion, a similar development could be traced: from the 'old' geography focusing on institutions and description of diffusion and manifestations of religion, the field moved to the 'new' geographies studying the mutually constructive relationship between religion and space with a special focus on the role of an ordinary person in this relationship. Both these developments follow a similar trend, simply put, from description to studying relationships between space and person. This common theoretical and empirical development encourages us to study the role of individuality of a person in the dynamic relationship between space and religion.

This paper develops this argument, discussing the current research of geographies of religion and arguing for the use of feminist approach. It argues that feminist approach allows to involve not only women's experiences and perception of religion and sacred space, but, in particular, to encourage research on religion in space at an everyday and personal level. Feminist geographies' focus on personal everyday experience can offer new insights into understanding of the relation between religion and space. Feminist approaches also reflect general societal trends in Czech society, which are connected with postmodernism and theorized as postsecularism in the sphere of religious changes. In postsecular society, religion is no longer only about visiting church on Sunday, but also about experiencing everyday moments through religious ethics and informal spiritual practice. Religion as a personal emotional everyday experience of space is a key factor in production of the individual identity of a person. Not only people who adhere some traditional religion, but also those who do not declare institutional religiosity experience their own spirituality. And the context of the mostly secularized space of Czechia highlights the individual dimension of religion which could be included within geographies of religion using feminist approaches.

Further, the discussion above led to assumption that religious experience with space reflects broader socio-cultural issues because religion importantly shapes individual's relation to the world through its norms and traditions. The everyday context of religious experiences is instructive to examine public issues (Dunn 2005) such as culture, politics, economics, integration, gender relations etc. For example, the currently topical problematic of migration and cultural integration could be approached trough the individual geographies of religion of actors. Therefore, understanding the contexts through which people of different religion individually perceive, construct and transform sacred spaces of everyday is important not only to the geographies of religion but also to the (new) cultural and social geography as whole.

\section{Acknowledgements}

The paper was supported by The Czech Science Foundation (grant number 17-08370S).

\section{References}

Aitchison, C., Hopkins, P., Kwan, M. P. (eds.) (2007): Geographies of Muslim identities: diaspora, gender, and belonging. Aldershot, Ashgate

Bailey, A. R., Harvey, D. C., Brace, C. (2007): Disciplining Youthful Methodist Bodies in Nineteenth-Century Cornwall. Annals of the Association of American Geographers 97(1), 142-157, https://doi.org/10.1111 /j.1467-8306.2007.00528.x.

Bartolini, N., Chris, R., Mackian, S., Pile, S. (2017): The Place of Spirit: Modernity and the Geographies of Spirituality. Progress in Human Geography 41(3), 338-354, https:// doi.org/10.1177/0309132516644512. 
Beaumont, J., Baker, C. (eds.) (2011): Postsecular Cities: Space, Theory and Practice. London, Continuum.

Beckford, J. (1992): Religion, Modernity and PostModernity. In Bryan R. Wilson (ed.): Religion. Contemporary Issues. London, Bellew, p. 19.

Berger, P. L. (ed.) (1999): The desecularisation of the world: Resurgent religion and world politics. Grand Rapids, Wm. B. Eerdmans Publishing.

Berghammer, C., Fliegenschnee, K. (2011): Developing a Concept of Muslim Religiosity: An Analysis of Everyday Lived Religion among Female Migrants in Austria. Journal of Contemporary Religion 29(1), 89-104, https://doi.org/10.1080/13537903.2014.864810.

Besio, K. (2007): In the Lady's Seat. Cosmopolitan women travellers in Pakistan. In Women, Religion and Space: Global Perspectives on Gender and Faith, ed. K. M. Morin, J. K. Guelke. Syracuse University Press, 81-110.

Brace, C., Bailey, A. R., Harvey, D. C. (2006): Religion, Place and Space: A Framework for Investigating Historical Geographies of Religious Identities and Communities. Progress in Human Geography 30(1), 28-43, https:// doi.org/10.1191/0309132506ph589oa.

Breitbart, M. M. (2003): "Participatory Research Methods." In Key Methods in Geography, edited by N Clifford and G Valentine, 141-56. London, Sage.

Cloke, P., Beaumont, J. (2013): Geographies of postsecular rapprochement in the city. Progress in Human Geography 37(1), 27-51, https://doi.org /10.1177/0309132512440208.

Davidson, J., Bondi, L., Smith, M. (2005): Emotional Geographies. Ashgate.

Della Dora, V. (2018): Infrasecular geographies. Progress in Human Geography 42(1), 44-71, https://doi.org /10.1177/0309132516666190.

Dewsbury, J. D., Cloke, P. (2009): Spiritual landscapes: existence, performance and immanence. Social and Cultural Geography 10(6), 695-711, https://doi.org /10.1080/14649360903068118.

Dowler, L., Sharp, J. (2001): A Feminist Geopolitics? Space and Polity 5(3), 165-176, https://doi.org/10.1080 /1356257012010438.

Dunn, K. M. (2005): Repetitive and Troubling Discourses of Nationalism in the Local Politics of Mosque Development in Sydney, Australia. Environment and Planning D: Society and Space 23(1), 29-50, https:// doi.org/10.1068/d388.

Dwyer, C. (1999a): Contradictions of community: Questions of identity for young British Muslim women. Environment and Planning A 31(1), 53-68, https:// doi.org/10.1068/a310053.

Dwyer, C. (1999b): Veiled meanings: British Muslim women and the negotiation of differences. Gender, Place and Culture: A Journal of Feminist Geography 6(1), 5-26. https://doi.org/10.1080/09663699925123.

Dwyer, C. (2015): Photographing Faith in Suburbia. Cultural Geographies 22(3), 531-538, https://doi.org $/ 10.1177 / 1474474014545300$.

Dwyer, C. (2016): Why does religion matter for cultural geographers? Social and Cultural Geography 17(6), 758-762, https://doi.org/10.1080/14649365.2016 .1163728 .

Dyck, I. (2005): Feminist geography, the "everyday", and local-global relations: hidden spaces of place-making.
Canadian Geographer 49(3), 233-243, https://doi.org /10.1111/j.0008-3658.2005.00092.x.

Eliade, M. (1959): The Sacred and the Profane: The Nature of Religion. New York, Harcourt, Brace and World.

Falah, G.-W., Nagel, C. R. (2005): Geographies of Muslim women: gender, religion, and space. New York, Guilford Press.

Fenster, T. (2007): Gender, Religion, and Urban Management. Women's Bodies and Everyday Lives in Jerusalem. In Karen M. Morin and Jeanne Kay Guelke (eds.): Women, Religion and Space: Global Perspectives on Gender and Faith. Syracuse, New York, Syracuse University Press, 41-60.

Finlayson, C. (2017): Church-in-a-box: making space sacred in a non-traditional setting. Journal of Cultural Geography 34(3), 303-323, https://doi.org/10.1080 /08873631.2016.1264262.

Finlayson, C. C. (2012): Spaces of faith: Incorporating emotion and spirituality in geographic studies. Environment and Planning A 44(7), 1763-1778, https:// doi.org/10.1068/a44580.

Gökariksel, B. (2007): A feminist geography of veiling: Gender, class and religion in the making of modern spaces and subjects in Istanbul. In K. M. Morin and J. K. Guelke (eds.), Women, Religion and Space: Global perspectives on gender and faith (61-80). Syracuse, New York, Syracuse University Press.

Gökariksel, B. (2009): Beyond the officially sacred: religion, secularism, and the body in the production of subjectivity. Social and Cultural Geography 10(6), 657-674, https:// doi.org/10.1080/14649360903068993.

Gökariksel, B. (2012): The intimate politics of secularism and the headscarf: the mall, the neighborhood, and the public square in Istanbul. Gender, Place and Culture 19(1), 1-20, https://doi.org/10.1080/0966369X .2011.633428.

Gökariksel, B., McLarney. E. (2010): Introduction: Muslim Women, Consumer Capitalism, and the Islamic Culture Industry. Journal of Middle East Women's Studies 6(3), 1-18, https://doi.org/10.2979/MEW.2010.6.3.1.

Gökariksel, B., Secor, A. (2015): Post-secular geographies and the problem of pluralism: Religion and everyday life in Istanbul, Turkey. Political Geography 46, 21-30, https://doi.org/10.1016/j.polgeo.2014.10.006.

Gökariksel, B., Secor, A. (2017a): The Post-Islamist Problematic: Questions of Religion and Difference in Everyday Life. Social and Cultural Geography 18(5), 645-664, https://doi.org/10.1080/14649365.2016 .1210669 .

Gökariksel, B., Secor, A. (2017b): Devout Muslim Masculinities: The Moral Geographies and Everyday Practices of Being Men in Turkey. Gender, Place and Culture 24(3), 381-402, https://doi.org/10.1080 /0966369X.2017.1314948.

Habermas, J. (2008): Notes on Post-Secular Society. New Perspectives Quarterly 24(5), 17-29.

Havlíček, T., Klingorová, K. (2018): City with or without God? Features of post-secularism in religious landscape of post-communist Prague. Social and Cultural Geography 19(6), 789-811, https://doi.org/10.1080 /14649365.2017.1312696.

Heelas, P. (1996): The New Age Movement: The Celebration of the Self and the Sacralization of Modernity. Basil, Blackwell 
Heelas, P., Woodhead, L. (eds.). (2005): The Spiritual Revolution: Why Religion Is Giving Way to Spirituality. Oxford, Blackwell.

Henkel, R. (2011): Are geographers religiously unmusical? Positionalities in geographical research on religion. Erdkunde 65(4), 389-399, https://doi.org/10.3112 /erdkunde.2011.04.05.

Henkel, R. (2014): The changing religious space of large Western European cities. Prace Geograficzne 137, 7-15, https://doi.org/10.4467/20833113PG.14.006.2151.

Holloway, J. (2003): Make-believe: Spiritual practice, embodiment, and sacred space. Environment and Planning A 35(11), 1961-1974, https://doi.org/10 $.1068 / a 3586$

Holloway, J. (2006): Enchanted Spaces: The Séance, Affect, and Geographies of Religion. Annals of the Association of American Geographers 96(1), 182-187. https://doi.org /10.1111/j.1467-8306.2006.00507.x.

Holloway, J., Valins, O. (2002): Editorial: Placing religion and spirituality in geography. Social and Cultural Geography 3(1), 5-9, https://doi.org/10.1080 /14649360120114107.

Hopkins, P. E. (2006): Youthful Muslim masculinities: Gender and generational relations. Transactions of the Institute of British Geographers 31(3), 337-352, https://doi.org/10.1111/j.1475-5661.2006 .00206.x.

Hopkins, P. E. (2007): Global events, national politics, local lives: Young Muslim men in Scotland. Environment and Planning A 39(5), 1119-1133, https://doi.org/10.1068 /a38129.

Hopkins, P. E. (2009): Women, men, positionalities and emotion: Doing feminist geographies of religion. ACME: An International E-Journal for Critical Geographies 8(1), 1-17.

Hopkins, P., Olson, E., Pain, R., Vincett, G. (2011): Mapping Intergenerationalities: The Formation of Youthful Religiosities. Transactions of the Institute of British Geographers 36(2), 314-327, https://doi.org/10 $.1111 /$ j.1475-5661.2010.00419.x.

Howe, N. (2009): Secular iconoclasm: purifying, privatizing, and profaning public faith. Social and Cultural Geography 10(6), 639-656, https://doi.org/10.1080 /14649360903068092.

Hunt, S. (2005): Religion and the Everyday Life. London, Routledge.

Ingersoll, J. (2003): Evangelical Christian women: War stories in the gender battles. New York, New York University Press.

Inglehart, R., Appel, D. (1989): The Rise of Postmaterialist Values and Changing Religious Orientations, Gender Roles and Sexual Norms. International Journal of Public Opinion Research 1(1), 45-75, https://doi.org/10.1093 /ijpor/1.1.45.

Inglehart, R., Norris, P. (2003): Rising Tide: Gender Equality and Cultural Change around the World. Cambridge, Cambridge University Press.

Klingorová, K. (2016): Feministické geografie náboženství: křestáanství v každodenním životě mladých žen. Geografie 121(4), 612-631, https://doi.org/10.37040 /geografie2016121040612.

Klingorová, K., Gökariksel, B. (2018): “God was with me everywhere": women's embodied practices and everyday experiences of sacred space in Czechia. Gender, Place and Culture 25(1), 37-60, https://doi.org/10.1080 /0966369X.2017.1398138.

Klingorová, K., Havlíček, T. (2015): Religion and gender inequality: The status of women in the societies of world religions. Moravian Geographical Reports 23(2), 2-11, https://doi.org/10.1515/mgr-2015-0006.

Klingorová, K., Vojtíšek, Z. (2018): Women’s everyday spirituality in Diamond Way Buddhism: an autophotographic study. Journal of Cultural Geography 35(3), 291-314, https://doi.org/10.1080/08873631.2017 .1375783

Kong, L. (2001): Mapping "new" geographies of religion: politics and poetics in modernity. Progress in Human Geography 25(2), 211-233, https://doi.org/10.1191 /030913201678580485.

Kong, L. (2010): 'Global shifts, theoretical shifts: Changing geographies of religion', Progress in Human Geography 34(6), 755-776, https://doi.org /10.1177/0309132510362602.

Luckmann, T. (1967): The Invisible Religions: The Problem of Religion in Modern Society. New York, MacMillan.

Mackian, S. (2012): Everyday spiritualities: Social and spatial worlds of enchantment. Basingstoke, Palgrave Macmillan.

McDowell, L., Sharp, J. P. (eds.) (1999): A Feminist Glossary of Human Geography. London, Arnold.

McGuire, M. B. (2008): Lived Religion: Faith and Practice in Everyday Life. Oxford, Oxford University Press.

Morin, K. M., Guelke, J. K. (eds.) (2007): Women, Religion and Space: Global perspectives on faith and gender. Syracuse, New York, Syracuse University Press.

Nast, H. J. (1994): Women in the Field: Critical Feminist Methodologies and Theoretical Perspectives. Professional Geographer 46(1), 54-66, https://doi.org /10.1111/j.0033-0124.1994.00054.x.

Nast, H., and Pile, S. (eds.) (1998): Places through the body. London, Routledge.

Nešpor, Z. R. (2018): 'Postsekularismus po česku? Ne/ religiozita současné české společnosti mezi Východem a Západem'. Střed 1,101-118. Available at: http:// religion-landscape.cz/download/papers/nespor_2018 _stred.pdf (Accessed: 17 January 2019).

Noland, C. M. (2006): Auto-Photography as Research Practice Identity and Self-Esteem. Journal of Research Practice 2(1), http://jrp.icaap.org/index.php/jrp/article /view/19/50.

Olson, E., Hopkins, P., Pain, R., Vincett, G. (2013): Retheorizing the Postsecular Present: Embodiment, Spatial Transcendence, and Challenges to Authenticity Among Young Christians in Glasgow, Scotland. Annals of the Association of American Geographers 103(6), 1421-1436, https://doi.org/10.1080/00045608.2012 .702516

Pain, R. (2004): Social Geography: Participatory research. Professional Geographer 28(5), 652-663, https://doi. org/10.1191/0309132504ph511pr.

Pinder, D. (2009): Everyday life. In Derek Gregory, Ron Johnston, Geraldine Pratt, Michael Watts a Sarah Whatmore (eds.): Dictionary of Human Geography. 5 th edition. Chichester, John Wiley and Sons Ltd., 223-225.

Pratt, G. (2009): Feminist geographies. In Gregory, D., Johnston, R., Pratt, G., Watts, M., Whatmore, S. (eds.): 
Dictionary of Human Geography. 5th edition. Chichester, John Wiley and Sons Ltd., 244-248.

Pringle, R. (1999): Emotion. In McDowell, L., Sharp, J. P. (eds.): A Feminist Glossary of Human Geography. London, Arnold, 68-69.

Rinschede, G. (1999): Religionsgeographie. Braunschweig, Westermann.

Rodaway, P. (1994): Sensuous Geographies: Body, sense and place. London, Routledge, https://doi.org /10.4324/9780203306864.

Sauer, B. (2009): Headscarf Regimes in Europe: Diversity Policies at the Intersection of Gender, Culture and Religion. Comparative European Politics 7, 75-94, https://doi.org/10.1057/cep.2008.41.

Secor, A. (2002): The Veil and Urban Space in Istanbul: Women's dress, mobility and Islamic knowledge. Gender, Place and Culture 9(1), 5-22, https://doi.org /10.1080/09663690120115010.

Secor, A. (2007): Afterword. In Morin, K. M., Guelke, J. K. (eds.): Women, Religion and Space: Global Perspectives on Gender and Faith. Syracuse University Press, 148-158.

Secor, A. J. (2003): Citizenship in the City: Identity, Community, and Rights Among Women Migrants to Istanbul. Urban Geography 24(2), 147-168, https:// doi.org/10.2747/0272-3638.24.2.147.

Seguino, S. (2011): Help or hindrance? Religion's impact on gender inequality in attitudes and outcomes. World Development 39(8), 1308-1321, https://doi.org /10.1016/j.worlddev.2010.12.004.

Sharp, J. (2009): Geography and gender: what belongs to feminist geography? Emotion, power and change.
Progress in Human Geography 33(1), 74-80, https:// doi.org/10.1177/0309132508090440.

Sheldrake, P. (2001): Spaces for the Sacred Place, Memory, and Identity. Johns Hopkins University Press.

Sturm, T. (2013): The future of religious politics: towards a research and theory agenda. Area 45(2), 134-140, https://doi.org/10.1111/area.12028.

Tomalin, E. (2013): Religion and Development. London, New York, Routledge.

Tse, J. K. H. (2014): Grounded theologies: "Religion" and the "secular" in human geography. Progress in Human Geography 38(2), 201-220, https://doi.org /10.1177/0309132512475105.

Vincett, G., Olson, E., Hopkins, P., Pain, R. (2012): Young People and Performance Christianity in Scotland. Journal of Contemporary Religion 27(2), 275-290, https://doi .org/10.1080/13537903.2012.675741.

Vojtíšek, Z. (2007): Nová náboženská hnutí a jak jim porozumět. Praha, Beta Books.

Wigley, E. (2016): The Sunday morning journey to church considered as a form of "micro-pilgrimage." Social and Cultural Geography 17(5), 694-713, https://doi.org /10.1080/14649365.2016.1139168.

Williams, A. (2015): Postsecular geographies: Theo-ethics, rapprochement and neoliberal governance in a faithbased drug programme. Transactions of the Institute of British Geographers 40(2), 192-208, https://doi.org /10.1111/tran.12069.

Woodhead, L. (2013): Gender Differences in Religious Practice and Significance. International Advances in Engineering and Technology 13, 58-85. 